\title{
How do Industries Respond to Finance Specific Regulations?
}

\section{David Rodriguez}

Department of Finance, High Point University, United States

\begin{abstract}
The immediate reaction of financial firms subject to the 2008 short sale ban has been examined in previous literature and showed largely positive reactions. This study examines the ban beyond just those firms subject to the ban and finds that reactions of the financial industry as a whole, and not just those firms that were subject to the ban, were not as clear and imply a lack of cohesion. Additionally, this study finds that the commonalities of those firms subject to the ban were, as suggested by media, minimal which implies that policy makers may not have produced the intended outcome. In an effort to elaborate on the potential of unintended outcomes an industry ripple analysis was completed and shows that particular sectors seem to follow the financial industry. Specifically, the finding is that capital intensive industries trended with the financial industry at the initial announcement. Understanding the interrelatedness amongst industries should assist in future policy implementations and business decisions.
\end{abstract}

Keywords: Short sale constraints; Firm selection; Industry response; Stock returns; Regulations

\section{Introduction}

The impact of the short sale ban of 2008 has been examined in detail with respect to the financial industry. However, it is evident that the response to the ban did not stop at the financial industry. While it can be argued that the financial industry is the backbone to the economy it is still necessary to examine the interrelatedness of industries in order to understand the magnitude of the emergency order. It is evident after examining literature that the goal of government intervention, in the form of short sale bans, has focused solely on the financial industry with minimal regard or consideration for the potential ripple.

Short selling has long been viewed by academics as a necessary tool in maintaining efficient pricing. Miller (1977) was amongst the first to address an overpricing hypothesis. Miller suggested that the observed price of a security only reflects the views of optimists that believe the security will outperform other investments. The implications of his findings are that securities may be overvalued in the presence of short selling restrictions. Research by Jarrow (1980) and Bris et al. [1] document shows that without the mechanism of short selling securities will tend to be overpriced. These studies confirm the fact that restricting firms will result in the overpricing of stocks. However, short selling is also viewed by skeptics as a speculative practice which disturbs the stability of financial markets and causes dramatic downward price pressure on securities that would not have occurred

${ }^{1}$ Aaron Smith, CNN "Fuld blames "crisis of confidence"' October 6, 2008. Joseph Giannone, Reuters "Morgan Stanley CEO blames rout on short sellers" September 18, 2008. Bloomberg Jesse Westbrook "Citigroup urging SEC to bring back short selling ban" November 20, 2008. Anderson, Jenny. S.E.C. Unveils measures to limit short-selling" July 162008

${ }^{2}$ Bloomberg. Westbrook, Jesse \& Edgar Ortega "SEC Stiffens Short-Selling Rules Amid Market Turmoil" September 17. BBC News 06/13/2008 "FSA cracks down on short selling". BBC News "Who's in the dock for the financial turmoil?" 09/19/2008. NYT Vikas Bajaj \& Graham Bowley "S.E.C. Temporarily Blocks Short Sales of Financial Stocks" September 19, 2008. Forbes Liz Moyer "Curbing Short Selling Abuse" July 15, 2008.

${ }^{3}$ The Wall Street Journal ("Naked Short Sales Provoke Complaints but No Cases") reported that SEC did not ban any cases of naked short selling even though they had received over 5,000 related complaints over the past 18 months. This report is not comforting since it implies the SEC's lack of ability to enforce. In support of the added efficiency, USA Today (8/14/2008) reported that the short selling ban was a success and that financial stocks suffered after the protection was lifted. CBS News reported on the SEC's action of permanently implementing the Naked short selling rule in an attempt to deter any future problems ("SECs "Naked" ShortSelling Rule Permanent" 07/27/09). otherwise. For example, executives from CitiGroup, Morgan Stanley, Lehman Brothers, and JP Morgan have each publically stated that short selling is either to blame, or a significant factor, to their negative security valuation in the 3 rd quarter of $2008^{1}$. During the peak of the financial turmoil, short selling had been promulgated to be a sizeable culprit to exaggerating the financial crisis. The SEC received 5,000 complaints in just over 18 months with regards to "aggressive" short selling. However, the SEC's enforcement staff minimized the likelihood of naked short selling abuses [2]. Then just a few months later, reports published in Forbes, Bloomberg, BBC News and New York Times, to name a few, all concluded that short selling was a major reason for the financial turmoil ${ }^{2}$. The critiques, coupled with the severity of the financial downfall, prompted U.S. government and governments around the globe to regulate short selling. Thirteen countries imposed short selling bans, with the United States as the first to announce such bans.

In the U.S., the first emergency order implemented by the Securities and Exchange Commission (SEC) took place on July 15, 2008. A major reason for enacting the emergency order was that, according to the management of several financial institutions, the market exaggerated their losses and sometimes even created rumors leading to runs on stock, producing valuation losses that had no merit. The unmerited rumors triggered intentional short selling from speculative investors, particularly those that adopted the practice called 'naked short selling'. Naked short sales refer to short selling without the action of preborrowing the security being shorted. Naked short selling facilitates the ease of short selling by saving investors the waiting time for the borrowing action to clear. This structure has led to these transactions being viewed as extremely speculative and thus volatility-inducing and price depressing ${ }^{3}$. Therefore, the first SEC emergency order directly targeted naked short selling, asking for a temporary restriction on naked short sales of 19 financial firms from July 21, 2008 to August 12, 2008.

*Corresponding author: David Rodriguez, Department of Finance, High Point University, United States, E-mail: drodrigu@highpoint.edu

Received June 24, 2013; Accepted September 04, 2013; Published September 09, 2013

Citation: Rodriguez D (2013) How do Industries Respond to Finance Specific Regulations? Bus Eco J 4: 079. doi: 10.4172/2151-6219.1000079

Copyright: () 2013 Rodriguez D. This is an open-access article distributed under the terms of the Creative Commons Attribution License, which permits unrestricted use, distribution, and reproduction in any medium, provided the original author and source are credited. 
This initial announcement and the response of the financial industry were examined by many authors. Boulton and Alves [3] found evidence of a positive market reaction to this initial restriction announcement, which reinforces the belief, as previously stated, that short selling may drive the stock price downwards. Additionally, the authors find that the restriction had a negative impact on various measures of market liquidity, which can be interpreted as reduced efficiency in pricing. As the market condition deteriorated, especially out of fear for an overall market panic at Lehman Brother's bankruptcy, the SEC announced a much more severe restriction on September 18, 2008 [4-7]. This prohibited short selling (naked or not) on 799 financial firms, including banks, insurance companies, and securities firms ${ }^{4}$. The emergency order became effective on September 19, 2008 and was scheduled to expire on October 2, 2008, though later the expiration date was extended to October 17, $2008[8,9]$. It is no surprise that with such a large number of firms "protected" under the September 18 short-sale ban the effect should be on a much larger scale than that documented in the July 15, 2008 naked-short ban.

While a reproduction of prior work was completed it has not be included in this paper since the results of previous literature were confirmed. Instead, this study will begin with a brief examination of the commonalities of firms subject to the ban. The goal of this is to identify similarities amongst those firms subject to the ban and to gain a better understanding of how the SEC came upon the financial firms to include in the ban. The second, and most significant, aspect of this paper examines industry responses to the ban. Given that the financial industry is considered the backbone of the economy it is worth investigating the response of other industries to a ban that focused on only this industry. The examination of all industries is necessary and unique since the positive influences that were intended for the finance industry produced an unintended, or at least unexamined, ripple throughout the economy as a whole.

Specifically, this paper studies the effects of the September 18, 2008 short sale ban through the following avenues. The first analysis, not included in detail, is an event study that examines the immediate market reaction to the announcement using the complete sample of 799 firms. Since this ban was extended, added on to, and then later expired, the ability to test these additional event dates for market reaction arose.

Once results of previous literature were confirmed for the included firms a cross sectional logit regression analysis was completed to examine similarities amongst firms. If the SEC had succeeded in their efforts one would expect to find the firms subject to the ban sharing common characteristics such as spread, size and turnover. The purpose here is to identify characteristics of firms that the SEC may have utilized when selecting firms to include in the ban.

The final analysis conducted in this paper is an event study of the market segmented by industry. The intent of this is to first confirm the trend in the financial industry as a whole since thousands of financial firms were not provided the SEC's blanket of protection. However, the unique contribution is to examine how other industries responded to this act that only focused on the financial industry. The implication of ignoring other industries individually, or ignoring the ripple effect, suggests that finance is believed to operate in a silo that must be addressed on an individual basis. A ripple effect in economics is when an event in one industry impacts others. This then ripples out to affect another industry. The economic crisis of 2008 may be viewed as the ripple effect in action. A plausible ripple is that the problem in the real estate market spreads to the finance industry and then into the retail, travel and service industries [10]. It can be contested that the financial industry's loose regulations may have begun the crisis and that the loose regulations led to the inflated real estate prices, which then rippled out to affect alternate supporting industries. Similarly, the ripple at the time of the ban could have impacted firms that relied most on the finance industry for financing; in other words those that are asset based or those that require funding using commercial paper. While this ban may have had an intended effect on the financial industry, it is not apparent that other industries responded favorably.

The remainder of this paper proceeds as follows: Section 1.1 is a review on literature of industry specific findings and short sales. This section also examines the contribution of this paper as a bridge between practitioners' research and academics' literature. Section 1.2 details the September 18, 2008 Emergency order, its subsequent extensions and final expiration. Section 2 describes the sample and methodology. Section 3 reports the results and implications. Finally, Section 4 and 5 discuss the results and present the conclusions.

\section{Previous literature}

While an investigation of short sale research is necessary, and follows below, it is the limited extent of literature on industry responses which is paramount to understanding the shortcomings. The extent of industry specific research was primarily completed in non-academic literature and was limited to industry specific conferences in the form of presentations or white papers. A report prepared for Edison Electric in February 2009 examined the utility industry, specifically the electric utility industry, which represents the second most capital-intensive sector in the United States [11]. The expectation was that due to the project demands the need for major investments was necessary. The expected infrastructure investment from 2010 to 2013 was $\$ 1.5$ trillion. The financial crisis impact was expected to increase the cost of capital for this capital-intensive industry. Given that much of the financing surrounding the industry is commercial paper it is to be expected that the cost of capital would increase. Furthermore, given the fact that Lehman Brothers had been a major dealer in commercial paper it is evident that this ripple should be significant.

A report by Energy Insights in 2008 reported that most CIOs in the Utility Industry were told to conserve cash by freezing or slowing down external spending in the short term, primarily due to the lack of commercial paper [12]. A similar report focusing on the renewable energy sector concluded that as a result of financing issues all projects with financing prior to October 2008 were moving forward while those projected to begin in 2009 were delayed [13]. Similar reports published by GlobalData in 2008 and the Energy Ministers Meeting in 2009 note that the credit crunch will hamper petroleum exploration and production companies [14]. The Economic and Social Commission for Western Asia (2009) examined the demand for oil and concluded that the rapid fall in demand is attributed, in part, to the lack of growth expected as a result of the financial crisis [15]. This resulted since growth was expected to reduce in OECD countries by $2.9 \%$ in 2010. Strategic Advisors in Global Energy(2009) added that not only will the lack of

${ }^{4}$ It did include several exceptions that included registered market makers, other market makers whose market making and hedging activities call for necessary short selling, and the execution of previously arranged short sale agreements. Additionally, the SEC also gave the national exchanges (NYSE, NASDAQ, and AMEX) the authority to add firms to the list or remove firms from the list after reviewing such requests by the firms themselves, as a result, the number of firms included in the ban altered as some firms requested to be added, while others were removed from the list. 
credit hinder some normal business operations but that the exploration and development programs are also hampered by the lower oil prices which led to downward revisions in profitability of projects [16]. This has led to the delay and cancellation of projects which is expected to also create a significant ripple.

The literature on other industries such as telecommunications and manufacturing also expected the financial crisis to have an impact but did not expect it to be detrimental. For example, a report distributed by the United Nations Industrial Development Organization (2009) found that the crisis did not impact the automotive industry in developing countries severely. In fact the crisis was regarded as a downward business cycle and not a structural crisis [17]. This led the industry to respond with traditional crisis management techniques such as temporary downsizing, cost reductions, retraining, etc.

In contrast to the limited amount of work on specific industries a voluminous amount of research examines the financial industry and the direct impact of the short sale ban to just this industry. Research has shown that short sellers are positive contributors to efficient pricing and imply that to restrict short selling is to restrict an efficient market. Diamond and Verrecchia (1987) model how short sale constraints impede the flow of private and negative information, causing overvalued securities when short selling is costly [18]. Charoenrook and Daouk [19] examine short sale regulations from 111 countries and find that when countries change from a regime where short selling is not possible to a regime where it is, stock prices increase. This increase is a result of reduced volatility and an increase in liquidity. Asquith et al. [20] find that short-sale constrained stocks underperform by a significant 215 bps per month on an equally weighted base, which again implies the reduced efficiency of these restrictions. Stocks are short-sale constrained when there is a strong demand to sell short and a limited supply of shares exists for borrowing. Nagel [21] finds that short-sale constrained stocks under react to bad cash-flow news and overreact to good news. Each of these findings can be viewed as confirmation to Miller's (1977) finding that without short selling the observed price will only reflect the view of optimists. This is because short-sale constraints hold negative opinions at bay, reducing the efficiency of the market, and thus the pricing. Boehmer et al. [22] find that, on average, short sellers are important contributors to efficient stock prices. Boehmer and $\mathrm{Wu}$ [23] show that short sellers enhance the informational efficiency of prices as short selling reduces deviations of transaction prices from a random walk. They also find that short selling accelerates the incorporation of public information into process.

Interestingly, it appears that the allowance of short selling and high short selling by volume produce a greater negative skewness. Bris et al. [1] examine 46 equity markets around the world and find evidence that in markets where short selling is prohibited market returns display less negative skewness. However, this does not imply that the market is more or less efficient but rather that there are less negative occurrences which can in fact lead to a more inefficient market since the market is not allowed to freely reflect downward pressures.

From earlier studies such as Senchack and Starks [24], Asquith and Meulbroek [25] and Desai et al. [26]; to more recent studies such as Boehmer et al. [22], a fair amount of the research on short selling all confirm that intense short selling is followed by depressed prices . Nevertheless, it must be noted that the presence of downward pressure does not imply exaggeration, mispricing, or inefficiency.

Boehmer et al. [27] found that on average, short sales made up $21.75 \%$ of trading volume for banned stocks in the six weeks leading up to the ban but only $7.72 \%$ during the ban itself. Presumably, these remaining short sales were made by market makers. They also find that the ban is associated with a significant share price increase for affected stocks and stocks subject to the ban had lower market quality as measured by spreads, price impact, and intraday volatility. Similarly, Harris et al. [28] used a factor-analytic model to extract common valuation information. They estimated that the ban led to substantial price inflation of the subject firms. This implies that the ban did have an effect; however, the question is whether it had an appropriate effect and if this effect was as narrow as it was intended to be, immediately influencing the financial industry. The extent of literature that surrounds the short sale ban is abundant as is the literature surrounding reactions to announcements. However, the current literature seems to focus only on those that were directly impacted by this ban, short sellers and, more specifically, the financial industry. The expansive scope of this paper will look to explore beyond the financial industry and attempt to gain a more complete picture of the effects of intervention.

\section{The emergency order of September 18, 2008}

On September 18, 2008 the SEC invoked its emergency powers under Section 12(k)(2) of the Securities Exchange Act of 1934, as amended, and issued an emergency ban in order to curtail the "unnecessary or artificial price movements based on unfounded rumors regarding the stability of financial institutions and other issuers exacerbated by 'short selling"' The orders implement a short sale prohibition, impose a short sale disclosure requirement on institutional money managers, strengthen clearance and settlement delivery requirements and adopt an anti-fraud rule that prescribes deceptive conduct in connection with a seller's intention or ability to settle its sell orders. The orders temporarily prohibit any person from completing a short sale in common stocks of a select 797 banks, insurance companies, and security firms until October 2, 2008 unless extended. As referred to in the Introduction Section of this paper, this is the second time that the SEC has invoked this right. Additionally, on September 21, 2008, the SEC issued an amended order delegating national security exchanges the power to add firms to the original list. The SEC also authorized the exchanges to exclude companies that elect not to be covered by the prohibition on short sales 5 .

The sequence of events for the emergency order began with the initial 799 firms that were included in the short sale ban announced on September 18, 2008. The ban was to take affect the next business day, Friday, September 19, 2008. There were an additional 77 firms, including banks, insurance companies and securities firms added Monday, September 22, 2008, after the close of the trading day. Over the next few weeks smaller adjustments were made to the list. The expiration of the short sale ban was extended on October 1, 2008 from the original expiration, October 2, 2008, to either October 17, 2008 or three businesses after the enactment of economic stability legislation. The Emergency Economic Stabilization Act of 2008 was signed on

${ }^{5}$ The exceptions to the short sale restriction are:1) Market makers that utilize short sales as part of bona fide market making and hedging activity related directly to bona fide market making in derivative securities based on Covered Securities or ETFs of which Covered Securities are a component; 2) Short sales that occur as a result of automatic exercise or agreement of options that occur as a result of the expiration/settlement of futures contracts in each case held prior to the Financial Firm Emergency Order (SEC Release No. 34-58592); 3) Short sales affected by the writers of call options resulting from assignment following exercise by the holder of the call; 4) Sales of covered securities pursuant to Rule 144 of the Securities Act of 1933. 
October 3, 2008 the ban expired on October 8, 2008 without further extension.

\section{Sample and Methodology}

In an effort to first confirm results of previous studies an event study was completed which included only the financial industry. After review of the Order, 20 of the 797 originally restricted firms were omitted due to lack of available data for the estimation period ${ }^{6}$. This led to an initial sample of 777 restricted firms each matched with an appropriate control firm. It is required that all matched firms be a financial firm with an SIC code in the range of 6000-6799. Creating a matched sample is possible since the original list prepared by the SEC was completed on a best effort basis and did not include all firms in the range of 6000-6799. In fact there are a total of 1004 firms that are in the SIC codes that were included in the original order, meaning that the SEC did not simply choose all firms in a select SIC range. If the scope is broadened to all firms that existed within the range of 6000-6799 a total of 3393 firms are found. Beyond ensuring that control firms fell within the financial industry SIC codes they were also matched on size, as measured by market value as of December of 2007. Due to the high number of sample firms and the need for a close match of peer firms, control firms were repeated multiple times. Of the 777 matched firms 526 were unique. Of the remainder firms that were multiples the largest proportion were used two or three separate times. Specifically, 112 matched firms were used twice and 32 were used three times. The question addressed here is whether or not this emergency order had its intended effect. The market response to the Emergency Order is examined through an event study with day 0 set as September 19,20087. In an effort to ensure that size was not driving results the market index is first the equally-weighted CRSP index and then the value-weighted CRSP index. The estimation period $(\mathrm{t})$ is from day -230 to day -31 . Since the Ban was extended on October 2, 2008 until October 17 2008, two more event studies were performed with October 2, 2008 as day 0 , as well as October 17, 2008.

\section{Logit regression}

To analyze what cross-sectional characteristics of the firms contribute to their inclusion into the Emergency Order and its extension several logit regressions were complete. Among the variables that were tested were profitability measures (ROE and ROA), size as measured by market capitalization and liquidity measures such as quoted spread, proportional quoted spread, effective spread and proportional effective spread. (Chordia et al., 2000; Glaser and Weber 2005) [29,30]. The resulting logit model that was tested is:

\section{$\log (P / 1-P)=\beta_{o}+\beta_{1}$ Spread $+\beta_{2}$ Turnover $+\beta_{3}$ Cap}

Here the dependent variable, likelihood of being subject to the ban, is predicted by spread which is equal to the proportional quoted spread, turnover which is equal to the logarithm of (1+ stock turnover) and cap which is equal to market capitalization. The analysis examines three periods, each consisting of 14 trading days. The pre-event period begins on August 29, 2008 and ends on September 18, 2008; the Event period begins on September 19, 2008 and ends on October 8, 2008; the post-event period, begins on October 9, 2008 and ends on October 28, 2008. Given policy intentions, the expectation is that those firms that exhibit greater volatility would increase the likelihood of being subject to the ban. Similarly, since a larger firm is more likely to have an effect on the market as a whole, the independent variable Cap was included to capture the larger firms' likelihood of inclusion in the ban.

Since the firms did not have a choice on their original inclusion this test examines the characteristics that are shared amongst included firms and may help in understanding how the SEC chose the 777 firms from the 3000 financial firms that were in existence during that time. The expectation would be that the more precise the SEC was in their intervention the smaller the ripple would be. This is because rather than the act being viewed as a last ditch effort it would have been viewed as a calculated, finely-tuned, measure.

\section{Industry based event study}

The event dates and methodology for this event study mirror those completed for the above referenced financial firms. Specifically, both a market model and Fama-French three factor model were adopted. While both models were completed the focus of this paper is dedicated the Fama-French three factor model (1993). The model is outlined as follows:

\begin{tabular}{|c|c|c|c|c|c|c|c|}
\hline & Agriculture & Construction & \multicolumn{2}{|c|}{ Finance } & Manufacturing & Nat. Resources & Pet. Industry \\
\hline \# Stocks & 11 & 39 & \multicolumn{2}{|c|}{1900} & 1443 & 84 & 167 \\
\hline \multicolumn{8}{|l|}{ Capitalization } \\
\hline Mean & $4,999,070$ & $1,406,481$ & \multicolumn{2}{|c|}{$1,358,268$} & $2,875,201$ & $3,493,628$ & $8,156,847$ \\
\hline St.Dev. & $12,446,720$ & $1,804,097$ & \multicolumn{2}{|c|}{$6,416,206$} & $12,107,249$ & $6,789,063$ & $31,043,416$ \\
\hline \multicolumn{8}{|l|}{ Volume } \\
\hline Mean & $1,521,826$ & $1,560,920$ & \multicolumn{2}{|c|}{$1,657,900$} & $1,605,721$ & $2,262,930$ & $1,762,451$ \\
\hline St.Dev. & $4,122,989$ & $2,493,919$ & \multicolumn{2}{|c|}{$16,214,572$} & $5,789,014$ & $3,818,375$ & $3,548,470$ \\
\hline & Services & \multicolumn{2}{|c|}{ Telecommunications } & \multicolumn{2}{|c|}{ Trade } & Transportation & Utilities \\
\hline \# Stocks & 558 & \multicolumn{2}{|c|}{136} & & & 115 & 131 \\
\hline \multicolumn{8}{|l|}{ Capitalization } \\
\hline Mean & $2,545,627$ & \multicolumn{2}{|c|}{$4,874,174$} & \multicolumn{2}{|c|}{$3,294,013$} & $2,747,677$ & $4,307,169$ \\
\hline St.Dev. & $15,240,977$ & \multicolumn{2}{|c|}{$16,725,122$} & & 815 & $6,469,325$ & $5,885,291$ \\
\hline \multicolumn{8}{|l|}{ Volume } \\
\hline Mean & 930,781 & \multicolumn{2}{|c|}{$2,470,070$} & \multicolumn{2}{|c|}{$1,215,036$} & $1,278,119$ & 985,612 \\
\hline St.Dev. & $4,086,899$ & \multicolumn{2}{|c|}{$7,974,203$} & & 648 & $3,247,867$ & $1,680,242$ \\
\hline
\end{tabular}

Table 1: Descriptive Statistics for Industries.

${ }^{6}$ The primary reason for these omissions was due to a lack of sufficient returns during the estimation period.

${ }^{7}$ Though the announcement was made in the late hours of the $18^{\text {th }}$ the ban did not take effect until the $19^{\text {th }}$. 


$$
R_{j t}=\alpha_{i}+\beta_{j} R_{m t}+s_{j} S M B_{t}+h_{j} H M L_{t}+\varepsilon_{j t}
$$

where $R_{j t}$ is the rate of return on the common stock of the $j^{\text {th }}$ firm on dayt.

The abnormal return for the common stock of the $j^{\text {th }}$ firm on day t is

$$
A R_{j t}=R_{j t}\left(\alpha_{i}+\beta_{j} R_{m t}+s_{j} S M B_{t}+h_{j} H M L_{t}+\varepsilon_{j t}\right)
$$

The cross-sectional average abnormal return is computed by summing the abnormal returns across all $\mathrm{N}$ firms:

$$
A R_{t}=\sum_{(j=1)}^{N} \frac{A R j t}{N}
$$

The cumulative abnormal return from day $t_{1}$ to $t_{2}, C A R\left(t_{1}, t_{2}\right)$ is:

$$
C A R_{t 1, t 2}=\sum_{t=t 1}^{t 2} A R t
$$

To test the statistical significance of $A R_{t}$ and $\operatorname{CAR}\left(t_{1}, t_{2}\right)$, a parametric Patell Z-statistic followed by a non-parametric generalized sign $\mathrm{Z}$ statistic.

This event study is unique since Compustat was used to create twelve distinct industry groups. Broadly speaking, the industries were agriculture, natural resources, petroleum, construction, finance and real estate, manufacturing, public administration, services, telecommunications, trade, transportation and utilities. Given the limited amount of industry work the expectation is that those industries that are more capital intensive, such as utilities and petroleum, would have a more immediate response while those considered less capital intensive, services and trade, may only produce delayed responses. Table 1 provides descriptive measures of the industries.
The Table 1 below segments the industries based upon SIC codes. The mean and standard deviation are large since there was no effort made to further divide the industries into deciles since the concern was with industry response.

\section{Results}

\section{Event study results}

Event study results of the financial industry using an equallyweighted market index and a value-weighted market index are not identical, as expected, but do provide insight into how the market reacted to the emergency order and its extensions. Both indexes were used here since several of the institutions are quite large and the intent was to reduce the potential for their ability to skew results. As expected the results confirmed previous findings as mentioned in the literature review and are not included here.

\section{Logit results}

In order to test the likelihood of a particular firm falling subject to the short ban a logit model was completed. The intent was to examine the characteristics that are most likely to have led a firm to become subject to the ban. The expectation was that the nearly 800 firms subject to the ban had several basic commonalities that led to their inclusion. Due to a lack of all variables, several firms were omitted. Since it was

\begin{tabular}{|c|c|c|c|c|c|c|c|}
\hline Predictor & $\beta$ & SE $\beta$ & $x^{2}$ & df & $\operatorname{Pr}>x^{2}$ & Odds Ratio & $\mathrm{p}$ (odds ratio) \\
\hline Constant & -0.0115 & 0.0224 & 0.2645 & 1 & 0.6071 & NA & \\
\hline Spread & -0.2587 & 0.1445 & 3.2066 & 1 & 0.0733 & 0.772 & 0.436 \\
\hline Turnover & 0.0442 & 0.0123 & 13.0248 & 1 & 0.0003 & 1.045 & 0.511 \\
\hline Cap & $-1.58 \mathrm{E}-08$ & 1.58E-09 & 75.1909 & 1 & $<.0001$ & 1 & 0.500 \\
\hline Test Overall model evaluation & & & $x^{2}$ & Df & $p$ & & \\
\hline Likelihood ratio test & & & 91.3946 & 3 & $<.0001$ & & \\
\hline Score test & & & 86.099 & 3 & $<.0001$ & & \\
\hline Wald test & & & 78.4594 & 3 & $<.0001$ & & \\
\hline
\end{tabular}
most common that the smaller firms did not have reportable earnings/ variables, it is likely that these were the firms that were omitted, resulting

\begin{tabular}{|c|c|c|c|c|c|c|c|}
\hline Predictor & $\beta$ & SE $\beta$ & $x^{2}$ & $\mathrm{df}$ & $\operatorname{Pr}>x^{2}$ & Odds Ratio & $\mathrm{p}$ (odds ratio) \\
\hline Constant & -0.035 & 0.0277 & 2.378 & 1 & 0.123 & NA & \\
\hline Spread & -1.4582 & 0.1286 & 128.5205 & 1 & $<.0001$ & 0.233 & 0.189 \\
\hline Turnover & 0.1586 & 0.012 & 174.2531 & 1 & $<.0001$ & 1.172 & 0.540 \\
\hline Cap & $-2.24 \mathrm{E}-08$ & 1.94E-09 & 133.2823 & 1 & $<.0001$ & 1 & 0.500 \\
\hline Test Overall model evaluation & & & $x^{2}$ & $\mathrm{df}$ & $p$ & & \\
\hline Likelihood ratio test & & & 398.9836 & 3 & $<.0001$ & & \\
\hline Score test & & & 355.9625 & 3 & $<.0001$ & & \\
\hline Wald test & & & 321.4028 & 3 & $<.0001$ & & \\
\hline
\end{tabular}
in a bias towards larger firms.

\begin{tabular}{|c|c|c|c|c|c|c|c|}
\hline Predictor & $\beta$ & SE $\beta$ & $x^{2}$ & df & $\operatorname{Pr}>x^{2}$ & Odds Ratio & $\mathrm{p}$ (odds ratio) \\
\hline Constant & -0.0809 & 0.0234 & 11.9688 & 1 & 0.0005 & NA & \\
\hline Spread & -0.2463 & 0.1286 & 3.6693 & 1 & 0.0554 & 0.782 & 0.439 \\
\hline Turnover & 0.1055 & 0.0114 & 85.4699 & 1 & $<.0001$ & 1.111 & 0.526 \\
\hline Cap & $-2.88 \mathrm{E}-08$ & 2.55E-09 & 128.402 & 1 & $<.0001$ & 1 & 0.500 \\
\hline Test Overall model evaluation & & & $x^{2}$ & df & $p$ & & \\
\hline Likelihood ratio test & & & 245.1478 & 3 & $<.0001$ & & \\
\hline Score test & & & 203.9667 & 3 & $<.0001$ & & \\
\hline Wald test & & & 177.1314 & 3 & $<.0001$ & & \\
\hline
\end{tabular}

Table 2: Logit regression summary results for the pre-event period. Regression outputs for likelihood of a particular firm being subject to the ban

Table 3: Logit regression summary results for the event period. Regression outputs for likelihood of a particular firm being subject to the ban.

Table 4: Logit regression summary results for the post-event period. Regression outputs for likelihood of a particular firm being subject to the ban. 
The pre-event period begins on August 29, 2008 and ends September 18, 2008; the event period begins September 19, 2008 and ends October 8, 2008. The final period, post, begins on October 9, 2008 and ends on October 28, 2008. During the pre-event period no firms were omitted and all data was present, creating a total day set of 21,756 days, half of which are for the sample firms and the other are the matched firms. The event period has a loss of fifty trading days due to firms delisting over the event period. The post period lost five matched firms throughout and eight sample firms, resulting in a total of 21,600 trading days, a final reduction of 156 trading days.

The model for the pre-event period is shown (Table 2). Within the pre-event period both turnover and market cap are statistically significant. Spread, defined as proportional quoted spread, is not significant. Though the coefficient estimates on a logit regression have no direct interpretation, the relationship between variables is evident. As turnover increases the probability of a firm subject to the announcement reduces. This means that firms with a higher turnover may be more likely to have fallen on the restricted list. The size of the firm also has a significant but opposite effect. As the size of the firm increases the likelihood of falling on the list is reduced. While this is not entirely practical this effect may be due to the overwhelming amount of smaller firms in the announcement.

The odds ratio is a most easily understood when converted to a probability. The conversion into probabilities was completed by doing the following;

\section{$\mathrm{p}=\exp ($ coefficient $) /(1+\exp ($ coefficient $))$.}

For both turnover and cap, the figures imply that a change in the variable will result in a 50-50 chance of affecting the possibility of a firm becoming subject to a ban. The spread variable results in an approximate probability increase of approximately $44 \%$. To convert the percentage back into an odds ratio you must adjust the percentage accordingly; odds ratio $=p /(1-p)$. The final conversion back to the coefficients is log (odds ratio).

The outcomes for the event period model Table 3, are similar to those of the pre-event period and are significant. Within this period both the spread and cap are negative and statistically significant. The turnover ratio is significant and positive implying that during the event period firms with a higher turnover had greater volatility and a higher chance of being subject to the ban.

The odds ratio for Cap implies that a change in this variable will result in a 50-50 chance of affecting the possibility of a firm being subject to a ban. The odds ratio on turnover implies just over a $50 \%$ chance in increasing the likelihood of being subject to a ban. The spread variable results in an approximate probability increase of $19 \%$.

The outcomes for the post event period model Table 4, are similar to those of the pre-event and event. Cap is negative and significant which implies that larger firms are less likely to be subject to the ban. Conversely, turnover is positive and significant which means that firms with higher turnovers are more likely to be subject to the ban.

All three period models were commonly significant even though the relationships were not identical over the three periods as would have been expected. However, when looking at the odds ratio and percentage increases it seems that an increase in each variable results in an equal probability in the likelihood of being subject to the ban. Put simply there is not an overwhelming significant variable that banned firms shared. This is slightly discomforting since it does not provide guidance for the policy implementation. It appears that these variables did not help the regulatory authorities make decisions on firms to restrict, which may lead to the question of how regulators picked nearly 800 firms to include on a ban almost overnight. With such a regulatory intense environment it would be ideal to identify firms that benefit from regulatory action in order to prevent blanket regulations. The lack of identifiable commonalities was expected and likely means that these firms were strewn together without forethought, which may also suggest that the implications of the ban were likely not considered in their fullest. This should result in a large and unexpected, possibly unwarranted, ripple. This final thought leads to the question of what potential ripple effects came as a result of this ban.

\section{The ripple-industry breakdown event study results}

The purpose of these tests is not to determine why each industry acts in a certain way but instead to show the interrelatedness of the market and to widen the net of reactions. This ripple effect is not easily explained, but the relationships should be acknowledged. While literature seems to focus on the financial industry, it is not entirely evident why regulators and the media failed to discuss other industries' reactions to this announcement and instead created two distinctive groups, the finance industry and the "rest".

The first item to note in Table 5 is that the finance industry reacted as expected. Regulators came to the rescue of the financial industry, but while the immediate and intended effects may have been reached for this industry it is not apparent that a benefit existed for the market as a whole but instead benefitted specific industries. More specifically, we

\begin{tabular}{|c|c|c|}
\hline & Finance $\mathrm{N}=2056$ (Included as reference) & Petroleum N=192 \\
\hline-1 & $0.39 \%\left(-5.486^{\star * \star}\right)$ & $-1.01 \%\left(-4.957^{\star \star \star}\right)$ \\
\hline 0 & $1.16 \%\left(4.794^{\star * *}\right)$ & $1.33 \%(1.254)$ \\
\hline 1 & $-0.69 \%\left(-6.015^{\star * *}\right)$ & $4.31 \%\left(9.343^{\star * *}\right)$ \\
\hline
\end{tabular}

Panel A: These industries reacted positively to the initial intervention.

\begin{tabular}{|c|c|c|c|c|c|}
\hline & Finance N=2056 (Included as reference) & Trade $\mathrm{N}=317$ & Manufacturing $\mathrm{N}=1567$ & Agriculture $\mathrm{N}=11$ & Services $N=604$ \\
\hline-1 & $0.39 \%\left(-5.486^{* * *}\right)$ & $-1.16 \%(-1.359)$ & $-0.03 \%(-0.229)$ & $-1.51 \%(0.621)$ & $0.56 \%(0.704)$ \\
\hline 0 & $1.16 \%\left(4.794^{\star * \star}\right)$ & $-2.43 \%\left(-5.744^{\star * *}\right)$ & $-0.81 \%\left(-3.872^{* \star *}\right)$ & $-4.45 \%(0.016)$ & $-0.71 \%\left(-1.985^{*}\right)$ \\
\hline 1 & $-0.69 \%\left(-6.015^{\star * *}\right)$ & $-0.42 \%(-0.909)$ & $-0.24 \%(-0.937)$ & $2.87 \%(0.621)$ & $-1.04 \%\left(-1.985^{*}\right)$ \\
\hline
\end{tabular}

Panel B: These industries reacted negatively to the initial intervention.

\begin{tabular}{|c|c|c|c|c|c|}
\hline & Natural Resources $\mathrm{N}=94$ & Construction $\mathrm{N}=43$ & Telecommunication $\mathrm{N}=148$ & Utilities $\mathrm{N}=139$ & Transportation $\mathrm{N}=124$ \\
\hline-1 & $-0.57 \%(-0.331)$ & $-4.27 \%(-0.523)$ & $0.60 \%(-0.804)$ & $-2.01 \%\left(-4.742^{* * *}\right)$ & $-1.73 \%\left(-3.275^{* * *}\right)$ \\
\hline 0 & $-0.87 \%\left(-1.983^{*}\right)$ & $-2.54 \%(0.701)$ & $-1.81 \%\left(-3.108^{* * *}\right)$ & $-2.12 \%\left(-4.572^{* \star *}\right)$ & $-2.09 \%\left(-2.376^{\star *}\right)$ \\
\hline 1 & $8.38 \%\left(6.072^{* * *}\right)$ & $2.39 \%(1.619)$ & $0.04 \%(0.512)$ & $1.81 \%\left(6.462^{* * *}\right)$ & $-0.76 \%(-1.477)$ \\
\hline
\end{tabular}

Table 5: Industry breakdown event study for the initial announcement. 
see that all but one industry, petroleum, reacted negatively to the initial announcement.

The industries are segmented based on SIC codes. Panel A for each respective date includes industries that responded favorably to the SEC's intervention. Panel B for each respective event date includes the industries that responded unfavorably to the SEC's intervention. ${ }^{* *}, * *$, and ${ }^{\star}$ denote statistical significance at the 1 percent, 5 percent, and 10 percent level, respectively.

At the initial announcement Table 5, we see a positive reaction in only one industry, petroleum, and negative reactions in nine industries with seven being significantly negative. The examination of this initial announcement window is the most useful since it provides the best picture of how industries replied to a financial industry specific regulation. As the expiration approached it became evident that the final solution, TARP, would be far stretching, which would likely confuses the results.

As seen in Table 5 only four of the nine industries that initially reacted negatively remain negative the following day. The remaining four reverse their direction with the exception of Natural Resources and Utilities, which are both capital intensive industries. The day following the initial announcement led to positive abnormal changes that were significant at one percent for each of these two industries. Telecommunications also reversed the following day but this positive move was not statistically significant. This is noteworthy since these three industries are capital intensive and seem to have ultimately viewed this ban as a welcomed intervention. Table 6 displays the industry response to the extension.

The industries are segmented based on SIC codes. Panel A for each respective date includes industries that responded favorably to the SEC's intervention. Panel B for each respective event date includes the industries that responded unfavorably to the SEC's intervention. ${ }^{* *},{ }^{* *}$, and ${ }^{\star}$ denote statistical significance at the 1 percent, 5 percent, and 10 percent level, respectively.

It is evident from the above table that capital intensive industries did not view the extension as favorable as they did the original

\begin{tabular}{|c|c|c|c|}
\hline Day & $\begin{array}{c}\text { Finance } \mathrm{N}=2061 \text { (Included as } \\
\text { reference) }\end{array}$ & Utilities $N=139$ & Telecomm N=150 \\
\hline-1 & $0.82 \%\left(7.070^{* * *}\right)$ & $-0.69 \%(-0.290)$ & $-0.36 \%(-0.617)$ \\
\hline 0 & $0.56 \%\left(10.287^{\star * *}\right)$ & $0.74 \%\left(3.445^{\star \star \star}\right)$ & $1.01 \%\left(3.306^{* * *}\right)$ \\
\hline 1 & $0.44 \%\left(5.836^{* * *}\right)$ & $0.35 \%\left(2.087^{\star}\right)$ & $0.26 \%(0.364)$ \\
\hline Day & Manufacturing $\mathrm{N}=1568$ & Services $N=604$ & Trade $\mathrm{N}=317$ \\
\hline-1 & $-0.11 \%(0.834)$ & $-0.49 \%\left(-1.776^{\star}\right)$ & $-1.14 \%\left(-2.930^{* *}\right)$ \\
\hline 0 & $0.07 \%\left(2.200^{*}\right)$ & $0.38 \%\left(2.707^{* *}\right)$ & $0.01 \%(1.568)$ \\
\hline 1 & $-0.38 \%\left(-1.999^{*}\right)$ & $-0.57 \%\left(-3.243^{\star * \star}\right)$ & $-0.56 \%\left(-1.806^{*}\right)$ \\
\hline
\end{tabular}

Panel A: These industries each reacted positively to the extended intervention.

\begin{tabular}{|c|c|c|c|}
\hline Day & $\begin{array}{c}\text { Finance } \mathrm{N}=2061 \text { (Included as } \\
\text { reference) }\end{array}$ & $\begin{array}{c}\text { Petroleum } \\
\text { Industry N=194 }\end{array}$ & $\begin{array}{c}\text { Natural } \\
\text { Resources } \mathrm{N}=95\end{array}$ \\
\hline-1 & $0.82 \%\left(7.070^{* * *}\right)$ & $-3.59 \%\left(-7.785^{* * *}\right)$ & $1.05 \%\left(1.855^{*}\right)$ \\
\hline 0 & $0.56 \%\left(10.287^{* * *}\right)$ & $-5.01 \%\left(-9.797^{* * *}\right)$ & $-5.70 \%\left(-5.954^{* * *}\right)$ \\
\hline 1 & $0.44 \%\left(5.836^{* * *}\right)$ & $-0.11 \%\left(1.700^{*}\right)$ & $1.58 \%\left(3.909^{* * *}\right)$ \\
\hline Day & Construction $\mathrm{N}=43$ & Agriculture $\mathrm{N}=11$ & Transportation $\mathrm{N}=125$ \\
\hline-1 & $1.75 \%(-0.258)$ & $-1.74 \%(-0.017)$ & $-0.34 \%(1.387)$ \\
\hline 0 & $-1.83 \%(-0.563)$ & $-0.72 \%(0.588)$ & $-1.48 \%\left(-1.745^{*}\right)$ \\
\hline 1 & $1.32 \%(1.578)$ & $-1.29 \%(-0.017)$ & $-0.72 \%(0.404)$ \\
\hline
\end{tabular}

Panel B: These industries each reacted negatively to the extended intervention.

Table 6: Industry breakdown event study for the extension announcement. announcement. Both the petroleum industry and the natural resources industry reacted negatively to this extension. However, several industries that are not generally considered capital intensive such as Trade and Services each reacted positively with Services significant at the five percent level. This equal industry split of positive and negative reactions on the extension date, for both capital intensive and non capital intensive industries, can be looked at as a general lack of faith in the actions of the SEC or as a muted response to an event that was expected. In any event when we look across industries we see that only two industries followed the pattern of the financial industry, telecommunications and utilities. The final table Table 7 shows the response of the industries to the expiration of the ban.

The industries are segmented based on SIC codes. Panel A for each respective date includes industries that responded favorably to the SEC's intervention. Panel B for each respective event date includes the industries that responded unfavorably to the SEC's intervention. ${ }^{* *},{ }^{* *}$, and ${ }^{\star}$ denote statistical significance at the 1 percent, 5 percent, and 10 percent level, respectively.

What we see above is that the expiration of the ban produced initial positive responses in only four of the eleven industries. However, the day immediately following the expiration showed a negative reaction in six industries. Once again we see that capital intensive industries were evenly split between their initial reactions to the expiration. These results are most difficult to interpret since the expiration of the ban came on the back of the bailout. The bailout had several key provisions for certain industries that could confuse the results. Was the market content that government intervention in the markets was coming to an end or was the market content with the greater bailout package that had industry specific provisions? For example, the 2008 Energy Insight report specifies several energy provisions that resulted from the more expansive policy such as one year extension of production tax credit for wind, two year extension of production tax credit for other renewable that already qualified, a new production tax credit for marine hydrokinetic energy, eight-year extension of $40 \%$ investments tax credit for solar energy, and a change in depreciation for smart meter and smart grid technologies from 20 to 10 years. As this energy example shows the level of industry specific components was substantial in the bailout. This fact results in the findings of the initial announcement being the cleanest and most practically significant.

While it is clear that the particular financial struggles and misfortunes (such as the subprime crisis) had a significant effect on the finance industry, it is unclear why the market responded in the fashion it did. The financial industry met expectations consistent with previous research but several peer industries seemed to respond significantly to this intervention too. A useful extension to this paper would be to examine the relationships within the industries that moved together as well as the ties that existed with the financial industry. The anecdotal evidence provided in the literature review is interesting but does not empirically examine these relationships. Is it as simple as these capital intensive industries relying more heavily on banking and that the reduction in funding or increased cost of capital hindered the market's expectations or is it something more? Have these most affected industries altered their funding sources or capital structure in order to avoid future potential issues that may arise as a result of the financial industry?

\section{Discussion}

The logit models show that variables that help differentiate firms from one another did not assist in determining firms that were subject 


\begin{tabular}{|c|c|c|c|}
\hline Day & Finance (Included as reference) $\mathrm{N}=2072$ & Petroleum Industry N=198 & Utilities N=139 \\
\hline-1 & $0.41 \%\left(4.655^{\star * *}\right)$ & $2.81 \%\left(5.167^{* * *}\right)$ & $1.64 \%\left(5.312^{\star * *}\right)$ \\
\hline 0 & $0.20 \%\left(2.568^{* *}\right)$ & $1.97 \%\left(3.887^{* * *}\right)$ & $0.65 \%(1.342)$ \\
\hline 1 & $0.00 \%(1.008)$ & $4.71 \%\left(9.007^{* * *}\right)$ & $0.37 \%\left(-1.796^{*}\right)$ \\
\hline
\end{tabular}

Panel A: These industries each reacted positively to the expiration of the intervention.

\begin{tabular}{|c|c|c|c|c|}
\hline Day & Finance (Included as reference) $\mathrm{N}=2072$ & Manufacturing N=1569 & Services N=608 \\
\hline-1 & $0.41 \%\left(4.655^{\star * *}\right)$ & $-0.15 \%\left(2.474^{* *}\right)$ & $-0.49 \%(-0.137)$ \\
\hline 0 & $0.20 \%\left(2.568^{* *}\right)$ & $-0.57 \%\left(-6.221^{* \star *}\right)$ & $-0.16 \%(-1.274)$ \\
\hline 1 & $0.00 \%(1.008)$ & $-0.44 \%\left(-2.885^{\star *}\right)$ & $-0.27 \%(1.546)$ & $-0.69 \%(-0.705)$ \\
\hline
\end{tabular}

Panel B: These industries each reacted negatively to the expiration of the intervention.

\begin{tabular}{|c|c|c|c|}
\hline Day & Telecommunications N=153 & Transportation N=125 & Natural Resources N=95 \\
\hline-1 & $-0.96 \%(1.312)$ & $1.97 \%\left(2.476^{* *}\right)$ & $-8.36 \%\left(-5.317^{\star * *}\right)$ \\
\hline 0 & $-1.40 \%\left(-2.085^{*}\right)$ & $-0.40 \%\left(-2.357^{\star *}\right)$ & $-1.19 \%(-0.796)$ \\
\hline 1 & $-0.98 \%\left(-1.762^{*}\right)$ & $-0.42 \%(-0.746)$ & $-0.30 \%(-0.826)$ \\
\hline
\end{tabular}

Table 7: Industry breakdown event study for the expiration announcement.

to the ban, both by mandate and by choice. This fact can imply that the firms subject to the ban did not have overwhelmingly similar characteristics. This should raise concern since it would appear that the ban was applied so quickly and with such a sweeping motion that there were no noteworthy commonalities among firms subject to the ban.

In May 2009 the Government Accountability Office noted that "industry officials stated that due to the rushed nature of the September emergency order and the temporary rule, a lot of uncertainty and confusion existed relating to the scope and application of the new requirements". It is interesting to note that even with this uncertainty the financial industry's reaction to the ban was significant. The ripple was also evident in particular industries. The initial ban led to significantly positive results in only one industry and the reverse of five other industries the day following the initial announcement, Table 5. The fact that only one industry trended with the Finance industry implies that the Ban did have a relatively concentrated impact. However since such a large number considered it a positive move the following day is not as easily explicable. The four positive responses to the expiration show that, in general, industries were in favor of eliminating the ban in favor of TARP, though not overwhelmingly. This is interesting since TARP was expected to be more of a robust, lasting and targeted approach versus the direct, and narrow, intervention was being halted in the financial industry. The expectation would be an overwhelming positive reaction to this change in policy. In any event it is necessary for regulators to not only examine the effects within the silo of finance but to also understand the ripples that come as a result of such an intrusion to the market. It is also useful for businesses to understand how their given industry responds to actions intended for the financial industry so that they can make appropriate adjustments.

\section{Conclusion}

The initial executive order announcement is not confused with other industry specific government interventions and thus produced the clearest picture of industry responses. The fact that all capital intensive industries had a positive reaction by Day 1 does show a level of consistency that revolves around the relationship between capital intensive industries and the finance industry. Since particular industries were seemingly so impacted by the financial industries turmoil it will prove interesting to examine, at a later date, if these industries altered funding sources and reliance on the financial industry to avoid future ripples caused by the financial industry. This may prove to be the reason why several capital intensive industries did react positively to the expiration of the ban.

\section{References}

1. Bris A, Goetzmann WN, Zhu N (2007) Efficiency and the Bear: Short Sales and Markets Around the World. Journal of Finance 62: 1029-1079.

2. Scannell K (2009) Naked Short Sales Provoke Complaints but No Cases. The Wall Street Journal.

3. Boulton TJ, Braga-Alves MV (2010) The Skinny on the 2008 Short-Sale Restrictions. Journal of Financial Markets 13: 397-421.

4. Security and Exchange Commission, Release No. 34-58592/September 18 2008.

5. Security and Exchange Commission, Release No. 58591/September 18, 2008

6. Security and Exchange Commission, Release No. 34-58588/September 18, 2008

7. Security and Exchange Commission, Release No. 34-58572/September 18, 2008

8. Security and Exchange Commission, Release No. 58723/October 2, 2008.

9. Security and Exchange Commission, Release No. 58724/October 2, 2008

10. Impact of the Financial Crisis on Oil \& Gas Exploration and Production Investment.

11. Edison Electric Institute (2009) The Financial Crisis and Its Impact on the Electric Utility Industry. Washington.

12. Nicholson R, Lenssen N, Blackmore K, Feblowitz J, Enbar N (2008) Impact of the Financial Crisis on Technology Spending in the Utility Industry. Energy Insights.

13. National Renewable Energy Laboratory (2009) Renewable Energy Project Financing: Impact of the Financial Crisis and Federal Legislation.

14. G8 Energy Ministers Meeting (2009) The Impact of the Financial and Economic Crisis on Global Energy Investment. Rome.

15. Economic and Social Commission for Western Asia (2009) The Impact of the Global Financial Crisis on the World Oil Market and its Implications for the GCC Countries.

16. Strategic Advisors in Global Energy (2009) The Financial Crisis and Its Impact on the Oil and Gas Industry.

17. United Nations Industrial Development Organization (2009) Impact of the Global Economic and Financial Crisis over the Automotive Industry in Developing Countries.

18. Diamond D, Verrecchia R (1987) Constraints on Short-Selling and Asset Price Adjustment to Private Information. Journal of Financial Economics 18: 277-311.

19. Daouk H, Charoenrook A (2005) A study of Market-Wide Short-Selling Restrictions.

20. Asquith P, Pathak PA, Ritter JR (2005) Short interest, institutional ownership, and stock returns. Journal of Financial Economics 78: 243-276.

21. Nagel S (2005) Short sales, institutional investors and the cross-section of stock returns. Journal of Financial Economics 78: 277-309. 
22. Boehmer E, Jones CM, Zhang X (2008) Which Shorts are Informed. Journal of Finance 63: 491-527.

23. Boehmer E, Wu J (2009) Short selling and the informational efficiency of prices. Unpublished manuscript, Texas A\&M University of Oregon.

24. Senchack AJ, Starks L (1993) Short-Sale Restrictions and Market Reaction to Short-Interest Announcements. Journal of Financial And Quantitative Analysis 28: 177-194.

25. Asquith P, Meulbroek L (1995) An empirical investigation of short interest. Division of Research, Harvard Business School.

26. Desai H, Ramesh K, Thisgarajan SR, Balachandran B (2002) An Investigation of the Informational Role of Short Interest in the Nasdaq Market. Journal of Financial 57: 2263-2287.

27. Boehmer E, Jones CM, Zhang X (2013) Shackling Short Sellers: The 2008 Shorting Ban. Review of Financial Studies 26: 1363-1400.

28. Harris LE, Namvar E, Phillips B (2013) Price Inflation and Wealth Transfer During the 2008 SEC Short-Sale Ban. The Journal of Investment Management.

29. Chordia T, Roll R, Subrahmanyam A (2000) Commonality in Liquidity. Journal of Financial Economics. 56: 3-28.

30. Glaser M, Weber M (2009) Which Past Returns Affect Trading Volume? Journal of Financial Markets 12: 1-31. 